\title{
ЕЛЕМЕНТИ ТЕХНОЛОГІЇ СТВОРЕННЯ ПАСОВИЩ ДЛЯ ОЛЕНЯ ЛІСОВОГО В УМОВАХ ВОЛЬЕРНОГО РОЗВЕДЕННЯ
}

\begin{abstract}
Проаналізовано рослинний та грунтовий покрив земель, виведених із сільськогосподарського користування під влаштування фермерського мисливського господарства. Видовий склад на території вольєра нараховує 60 видів рослин, більшість 3 яких представлена різнотрав'ям, а основні злаки характеризуються низькою кормовою цінністю. Бобові представлені тільки розкиданими екземплярами горошку мишачого (Vicia cracca L.) та конюшини повзучої (Trifolium repens L.). Tака невелика кількість цінних злакових і бобових трав зумовлює необхідність докорінного покращення наявних пасовищ. Виявлено низьку забезпеченість грунтів досліджуваної території поживними елементами, низький ступінь гумусованості, кислу реакцію середовища. Характеристики грунту зумовлюють використання як бобового компонента травосуміші лядвенцю рогатого (Lotus corniculatus L.) та конюшини гібридної (Trifolium hybridum L.). Запропоновано в умовах Полісся Західного на середньозволожених луках із мінеральними грунтами на територіях, виведених із сільськогосподарського використання, залужувати пасовища для оленя лісового (Cervus elaphus L.) сумішами із тимофіївки лучної (Phleum pratense L.), грястиці збірної (Dactylis glomerata L.), пажитниці багаторічної (Lolium perenne L.), лядвенцю рогатого та конюшини гібридної.

Ключові слова: Cervus elaphus; фермерське мисливське господарство; бобово-злакова травосуміш; докорінне покращення; загін.
\end{abstract}

Вступ. На сьогодні фермерське мисливське господарство в Україні не набуло належного поширення. Однак воно активно розвивається в європейських країнах (Khoyetskyy, 2012). Тут на загороджених територіях утримують один або два види оленеподібних, рідше більше видів. Так, у Швеції у вольєрі Еріксберг на площі понад 900 га утримують оленя лісового та Давида, зубра, лань, дику свиню. М'ясо ратичних характеризується низьким вмістом холестерину і користується популярністю серед жителів Свропи, що зумовило активний розвиток фермерського мисливського господарства. Вольєр в Еріксберзі, як і більшість вольєрів у Європі, багатофункціональний, окрім розведення тварин для отримання м'яса, восени полюють і добувають оленів, диких свиней нагоном або з підходу. Окрім полювання, отримання м'ясної продукції, на фермерських мисливських господарствах розводять оленів для отримання племінних тварин з подальшою реалізацією.

На початку XXI ст. в Україні i, зокрема у Західному регіоні країни, з'явилися перші фермерські мисливські господарства, в яких утримують оленя лісового (Cervus elaphus L.). Успішність цього напряму мисливського господарства залежить від науково-практичних рекомендацій, розроблення бізнес-плану з організації фермерського мисливського господарства із розведення ра- тичних видів. Однією із проблем утримання оленів $є$ їх якісна підгодівля і хороші пасовища. Тому бізнес-план повинен грунтуватися на попередніх польових дослідженнях. Одним 3 аспектів досліджень $є$ аналіз умов і вивчення видового складу кормів у межах території, відведеної під влаштування вольєрів. Фермерське розведення оленів передбачає утримання їх у загонах. У літній період загони повинні характеризуватися достатньою кількістю пасовищного корму, високою якістю кормової біомаси.

Тому мета роботи - розроблення заходів та елементів технології із покращення літніх пасовищ оленя лісового в умовах фермерського мисливського господарства.

Об'скт та методи дослідження. Дослідження проводили у Ківерцівському р-ні Волинської обл. Територія відведена під влаштування фермерського мисливського господарства площею понад 150 га - землі, які виведено із сільськогосподарського користування і належать Дернівській сільській раді. Попередньо визначали фізико-хімічні властивості грунтів відповідно до загальноприйнятих методик (T. Bedernichek): $\mathrm{pH}$ - потенціометрично (ДСТУ ISO 10390:2007), вміст гумусу - за методом Тюріна в модифікації Нікітіна (ДСТУ 4289:2004), вміст рухомого фосфору та обмінного ка-

Інформація про авторів:

Бугрин Любомир Мирославович, канд. с.-г. наук, ст. науковий співробітник, завідувач відділу кормовиробництва. Email: blmkr@meta.ua

Партика Тетяна Володимирівна, канд. біол. наук, ст. науковий співробітник сектору агрохімії. Email: tetyana.partyka@gmail.com

Похалюк Олег Миколайович, аспірант кафедри лісівництва. Email: pokhalyuk.om@gmail.com

Цитування за ДстУ: Бугрин Л. М., Партика Т. В., Похалюк О. М. Елементи технології створення пасовищ для оленя лісового в умовах вольєрного розведення. Науковий вісник НлтУ України. 2018, т. 28, № 2. С. 37-40.

Citation APA: Bugryn, L. M., Partyka, T. V., \& Pokhaliuk, O. M. (2018). Some Technics of Pastures Creation for Red Deer in Aviary Farming. Scientific Bulletin of UNFU, 28(2), 37-40. https://doi.org/10.15421/40280205 
лію - за методом Кірсанова (ДСТУ 4289:2004), лужногідролізований азот - за методом Корнфілда. Також проведено опис видового складу трав'яного покриву угідь (V. Mazepa, P. Khoietskyi).

Результати дослідження та їх обговорення. Внаслідок існування у природних умовах ратичні види тварин пристосувалися до живлення кормами, які містять певну кількість поживних речовин, необхідних для їх виживання. Склад кормів оленя лісового різноманітний і змінюється залежно від біотопу. У його раціоні зареєстровано близько 30 деревних і чагарникових видів i понад 70 видів трав'янистих рослин. У літній період основою вольєрного розведення оленя $\epsilon$ утримання на пасовищах, розділених на загони. Здійснюють незначну підгодівлю зерновідходами, олені мають доступ до води, солі. Збалансований раціон забезпечує швидкий ріст молодняка, розвиток рогів у самців із значними трофейними якостями, істотну плодючість самок та ін. Без повноцінного живлення звірі не можуть реалізувати свій генетичний потенціал, що призводить до необхідності створення високопродуктивних пасовищ.

Оскільки у літній період утримання оленів тип годівлі трав'яно-концентратний, то основне навантаження кормової бази лягає на виробництво зеленої маси 3 культурних пасовищ. Для пасовищного використання потрібно створювати спеціальні травостої з рослин, які добре витримують багаторазове випасання і витоптування. Згідно $з$ дослідженнями, на території вольєра зареєстровано 60 видів рослин. Більшість 3 них представлена різнотрав'ям, а основні злаки характеризуються низькою кормовою цінністю (щучник дернистий (Deschampsia cespitosa (L.) P. Beauv.), куничник наземний (Calamagrostis epigeios (L.) Roth.)), за винятком невеликих кількостей тимофіївки лучної (Phleum pratense L.) та очеретянки звичайної (Phalaris arundinacea L.). За результатами видового аналізу, бобові представлені у невеликій кількості тільки розкиданими екземплярами горошку мишачого (Vicia cracca L.) та конюшини повзучої (Trifolium repens L.). Оскільки у природному травостої збереглися менше 25 \% цінних злакових і бобових трав, тому для забезпечення оленів поживними кормами потрібне докорінне покращення наявних пасовищ (Zinchenko, 2005).

Першим етапом покращення є підготовчі роботи, до яких належить знищення наявних чагарників і дрібнолісся, розрівнювання купини. Після розчищення проводять обробіток грунту. Для обробітку шару застосовують важкі дискові борони БДН-2, навісний плуг ПЛН5-35, навісний культиватор важкі водоналивні гладенькі котки КГВН-1,6. Оранку проводять восени на зяб на глибину 25-27 см плугом із передплужником. Навесні зачиняють вологу боронуванням у два сліди, здійснюють культивацію та сівбу трав зерно-трав'яною сівалкою з обов'язковим коткуванням до і після посіву.

Підбір травосуміші здійснюють із врахуванням потреб тварин у кормі та характеристик грунту. Ріст та потреба в енергії в оленів змінюються залежно від сезону. Вони пристосовані до ефективного використання короткого літнього періоду вегетації, тому взимку їх ріст сповільнюється. Апетит також істотно залежить від сезону: у самок він максимальний у період літнього сонцестояння, а мінімальний - під час зимового. Самці найменше споживають корму у період гону. Влітку відбувається швидкий ріст тварин, тому в цей період олені потребують високопоживного корму (Wairimu \& Hudson, 1993; Jiang \& Hudson, 1994; Cook et al., 2016).

Для забезпечення цієї потреби у Канаді для створення культурних пасовищ використовують високопродуктивні бобово-злакові травосуміші на основі люцерни (Pasture and Forages for Wapiti). Злаки легше адаптуються до несприятливих умов (важких, кислих грунтів), тому вони швидше розвиваються і переважають у травостоях. Якщо середовище сприятливе для бобових багаторічних трав, то шляхом підбору злаків, використанням і удобренням можна регулювати рівновагу видового складу травостою (Veklenko et al., 2011). У підборі бобово-злакових травосумішей важливо, щоб бобові багаторічні трави забезпечували високу врожайність у змішаному травостої, а злакові компоненти, сприяючи формуванню пружної дернини і збалансованості корму, не пригнічували їх. Тому для підвищення продуктивності та поліпшення кормової якості бобово-злакового травостою під час пасовищного використання передусім потрібно підбирати бобові компоненти.

Однак в умовах Західного Полісся природні умови не дають змоги вирощувати люцерну. Грунти досліджуваної території характеризуються здебільшого кислою реакцію середовища, ступінь їх гумусованості дуже низький (1,07-1,32\%). Забезпечення грунту рухомим фосфором і обмінним калієм у грунтах здебільшого низьке і дуже низьке, хоча трапляються ділянки із середнім вмістом цих елементів (21,0-96,4 мг/кг $\mathrm{P}_{2} \mathrm{O}_{5}$ та 20,1-97,0 мк/кг К 2 ). Значення вмісту лужногідролізованого азоту також дуже низькі (33,6-93,8 мг/кг). Тому найоптимальнішим для цих умов буде використання в ролі бобового компонента лядвенцю рогатого (Lotus corniculatus L.) та конюшини гібридної (Trifolium hybri$d u m$ L.), які найкраще переносять кислу реакцію грунту до 4,5 одиниць.

Злакові компоненти повинні бути представлені різними біологічними групами - нещільнокущовими і кореневищними видами. В умовах Західного Полісся на середньозволожених луках із мінеральними грунтами висівають у суміші тимофіївку лучну (5-6 кг/га), кострицю лучну (Festuca pratensis Huds., 7-8), грястицю збірну (Dactylis glomerata L., 4-5), або стоколос безостий (Bromus inermis Leyss., 6-8), пажитницю багаторічну (Lolium perenne L., 4-5 кг/га). На торфових грунтах замість пажитниці багаторічної, яка вимерзає, висівають 3-4 кг/га костриці червоної (Festuca rubra L.) або тонконогу лучного (Poa pratensis L.). На площах з частим перезволоженням висівають трави, стійкі до надмірного зволоження: лисохвіст лучний (Alopecurus pratensis L., 7-8 кг/га), очеретянку звичайну (канарник) (56), кострицю очеретяну (Festuca arundinacea Schreb., 68), тонконіг болотний (Poa palustris L., 3-5), мітлицю білу (Agrostis stolonifera L., 2-3 кг/га). У разі нестійкого зволоження доцільно використовувати кострицю червону (Bohovin, 2009). Такі травосуміші здатні забезпечити до 7,8 т/г сухої речовини із містом сирого протеїну до $10,57 \%$. Загальний вихід сирого протеїну становить 0,61-0,82 т/га (Veklenko et al., 2015).

Посів травосуміші проводять зерно-трав'яною сівалкою розкиднорядковим способом. Насіння пажитниці багаторічної, грястиці збірної, костриці червоної сіють в рядки через сошники на глибину $0,5-1,5$ см, а бобових компонентів та тимофіївки лучної - в розкид по поверхні з меншого насіннєвого ящика. У рік посіву не 
рекомендують випасати травостій, якщо не використовували покривну культуру. За весняного безпокривного способу сівби в разі досягнення висоти рослин 25$30 \mathrm{~cm}$ травостій скошують, цим самим Знищуючи i бур'яни.

Враховуючи низький рівень забезпечення грунту поживними елементами, для отримання високопродуктивних пасовищ обов'язковим є внесення мінеральних добрив. Перед сівбою багаторічних трав рекомендовано вносити мінеральні добрива у дозі $\mathrm{N}_{60} \mathrm{P}_{60} \mathrm{~K}_{90}$ (Veklenko et al., 2015). Восени вносять фосфорні і калійні добрива у дозі $\mathrm{P}_{60} \mathrm{~K}_{90}$ та підживлюють злакові трави азотними навесні у дозі $\mathrm{N}_{60}$ кг/га діючої речовини. Весняне внесення розділяють на два етапи: не менше $60 \%$ норми добрив вносять до початку активного росту і розвитку травостою (одразу після відновлення вегетації), а решту - після першого циклу пасовищного використання.

Кращим способом використання травостою є дрібнозагінний випас, за якого тварини перебувають в одному загоні 1-2 дні, а також порційний, коли вони на одній ділянці перебувають не більше 3-4 год. Максимальний ефект від порційного випасу досягається після стравлювання перерослого травостою (більше 30 см).

Випасання травостою доцільно починати після досягнення ним пасовищної стиглості, тобто за висоти 15-25 см, причому стравлювання починати 3 тих загонів, у травостої яких переважають ранньостиглі види злакових трав. Другий цикл доцільно розпочинати через 20-25 днів від початку першого. Загони, які тварини не встигли випасти до початку колосіння злакових трав, скошують для заготовлення кормів на зиму.

За пасовищний період проводять до 4-5 циклів стравлювання. Період між двома циклами стравлювання бобово-злакового травостою може змінюватися навесні в межах 20-25 діб, у середині літа - 30-35 діб, восени - 45-50 діб. Випасання тварин організовували таким чином, щоб початок стравлювання кожного року розпочинати 3 різних загонів. Перемінне сінокісно-пасовищне використання збільшує життєздатність рослин і продуктивність пасовищ.

Окрім цього, до системи догляду за культурними пасовищами входять: підкошування не з'їдених решток, підживлення травостою органічними і мінеральними добривами, підсів трав на зріджених ділянках, боротьба з бур'янами (у разі сильного забур'янення травостою), розгрібання калових купин.

Висновки. Створення фермерських мисливських господарств на землях, які не придатні або не використовують для ведення сільського господарства, дають змогу ефективно освоювати місцевості, створювати нові робочі місця.

Необхідною передумовою створення пасовищ для розведення оленя лісового $є$ дослідження наявного рослинного покриву та вивчення основних властивостей грунтів. За незадовільних характеристик наявних рослинних фітоценозів проводять докорінне покращення природних кормових угідь.

Важливим етапом у створенні культурних пасовиш $\epsilon$ підбір травосуміші та, особливо, iï бобового компонента. При цьому потрібно враховувати характеристики грунтового покриву, особливості зволоження території, проектований термін використання. В умовах Західного Полісся на середньозволожених луках із мінеральними грунтами висівають у суміші тимофіївку лучну, грястицю збірну, пажитницю багаторічну, лядвенець рогатий, конюшину гібридну. Такі травосуміші здатні забезпечити до 7,8 т/г сухої речовини із вмістом сирого протеїну до $10,57 \%$.

\section{Перелік використаних джерел}

Bohovin, A. V. (2009). Vymohy do vyboru vydiv trav i travosumishei dlia stvorennia siianykh luk riznoho hospodarskoho vykorystannia. [Requirements for the selection of perennial grass and grass mixture species for creation sowing grasslands of various economic uses]. Scientific Magazine of NSC "Institute of Agriculture", 3, 112-120. [in Ukrainian].

Canada. (2015). Agriculture Knowledge Centre. Pasture and Forages for Wapiti. Retrieved from: http://publications.gov.sk.ca/details.cfm? $\mathrm{p}=85281$

Cook, J. G., Cook, R. C., Davis, R. W., \& Irwin, L. L. (2016). Nutritional ecology of elk during summer and autumn in the Pacific Northwest. Wildlife Monographs, 195(1), 1-81. https://doi.org/10.1002/wmon.1020

Jiang, Z., \& Hudson, R. J. (1994). Seasonal energy requirements of wapiti (Cervus elaphus) for maintenance and growth. Canadian Journal of Animal Science, 74(1), 97-102. https://doi.org/10.4141/cjas94-015

Khoyetskyy, P. B. (2012). Lisomyslyvske hospodarstvo Zakhidnoho rehionu Ukrainy: istoriia rozvytku, suchasnyi stan, potensial myslyvskoho fondu. Doctoral dissertation for Agricultural Sciences (06.06.03 - Silvics and forestry). Lviv. 550 p. [in Ukrainian].

Veklenko, Y. A., Dudchenko, V. I., \& Kharchuk, A. S. (2011). Influence of herbage mixtures, sowing rates of components on the productivity of grass stands of perennial herbages of the hay-crop and pasture use. Feeds and Feed Production, 70, 124-129. [in Ukrainian].

Veklenko, Yu. A., Dudchenko, V. I., \& Kharchuk, A. S. (2015). Urozhainist bahatorichnykh pasovyshchnykh travosumishok riznoi intensyvnosti dozrivannia v umovakh zakhidnoho Polissia. [The yield of perennial pasture grass mixtures with different intensity of maturation in the conditions of western Polissya.]. Feeds and Feed Production, 80, 163-168. [in Ukrainian].

Wairimu, S., \& Hudson, R. J. (1993). Foraging dynamics of wapiti stags (Cervus elaphus) during compensatory growth. Applied Animal Behaviour Science, 36(1), 65-79. https://doi.org/10.4141/cjas94-015

Zinchenko, O. I. (2005). Kormovyrobnytstvo. [Forage production]. (2nd ed.). Kyiv: Vyshcha osvita. 448 p. [in Ukrainian]

Л. М. Бугрын ${ }^{\mathbf{1}}$, Т. В. Партыка ${ }^{\mathbf{1}}$ О. М. Похалюк ${ }^{\mathbf{2}}$

${ }^{1}$ Институт сельского хозяйства Карпатского региона НААН, с. Оброшине, Украина ${ }^{2}$ Национальный лесотехнический университет Украины, г. Львов, Украина

\section{ЭЛЕМЕНТЫ ТЕХНОЛОГИИ СОЗДАНИЯ ПАСТБИЩ ДЛЯ ОЛЕНЯ ЛЕСНОГО} В УСЛОВИЯХ ВОЛЬЕРНОГО РАЗВЕДЕНИЯ

\footnotetext{
Проведен анализ растительного и почвенного покрова земель, выведенных из сельскохозяйственного пользования под создание фермерского охотничьего хозяйства. Видовой состав на территории вольера насчитывает 60 видов растений, большинство из них представлено разнотравьем, а основные злаки характеризуются низкой кормовой ценностью. Бобовые представлены лишь разбросанными экземплярами горошка мышиного (Vicia cracca L.) и клевера ползучего (Trifolium repens L.). Такое небольшое количество ценных злаковых и бобовых трав создает необходимость коренного улучшения существу-
} 
ющих пастбищ. Выявлены низкая обеспеченность почв исследуемой территории питательными элементами, низкая степень гумусированости, кислая реакция среды. Такие характеристики почвы обусловливают использование как бобового компонента травосмеси лядвенца рогатого (Lotus corniculatus L.) и клевера гибридного (Trifolium hybridum L.). Предложено в условиях Полесья Западного на среднеувлажненных лугах с минеральными почвами на территориях, выведенных из сельскохозяйственного использования, использовать на пастбищах для оленя лесного (Cervus elaphus L.) травосмеси из тимофеевки луговой (Phleum pratense L.), ежи сборной (Dactylis glomerata L.), райграса многолетнего (Lolium perenne L.), лядвенца рогатого и клевера гибридного.

Ключевые слова: Cervus elaphus; фермерское охотничье хозяйство; бобово-злаковая травосмесь; коренное улучшение; загон.

L. M. Bugryn', T. V. Partyka1, O. M. Pokhaliuk ${ }^{2}$

${ }^{1}$ Institute of agriculture of the Carpathian region NAAS, Obroshine, Ukraine

${ }^{2}$ Ukrainian National Forestry University, Lviv, Ukraine

\section{SOME TECHNICS OF PASTURES CREATION FOR RED DEER IN AVIARY FARMING}

Hunting farms are actively developing in Canada, the USA, Australia, and European countries; however they are not so wellspread in Ukraine. Most European aviaries are multifunctional as in addition to breeding such animals as red deer, Père David's deer, bison, wild pig for meat, they organize hunts in the autumn. The first hunting farms with red deer (Cervus elaphus L.) appeared in Ukraine, particularly in the western region of the country, at the beginning of the 21 century. One of the problems of keeping deer is need in high-quality forages and good pastures. Deer farm breeding involves keeping animals in cages. In the summer, they should be provided with a sufficient amount of pastures, and also high quality feed biomass. Therefore, the purpose of this work is to develop some measures and elements of technology for improving summer pastures for red deer in the conditions of hunting farms. Creation of pastures for hunting farms require previous field studies of composition of grass species within the territory reserved for the installation of aviaries. According to the researches, 60 types of plants have been registered on the studied area in Western Polissya, Ukraine. Most of them are grasses with low fodder value (Deschampsia cespitosa (L.) P. Beauv., Calamagrostis epigeios (L.) Roth.), with the exception of small amounts of Phleum pratense L. and Phalaris arundinacea L. According to the results of the species analysis, the legumes are represented only by scattered specimens of the Vicia cracca L. and Trifolium repens L. Since less than $25 \%$ of valuable grass and legumes are preserved in natural herbage, radical improvement of existing pastures is essential for the provision of deer nutrition. Alfalfa is usually recommended as the main component of grass mixture for deer pastures, although conditions of studied area are not favourable for alfalfa cultivation. The soils of the studied territory are characterized mainly by the acidic reaction, their humus and nutrients content is low. Thus, Lotus corniculatus L. and Trifolium hybridum L. are supposed to be the most suitable as legume component for these conditions. The cereal components must be represented by various biological groups. Grass mixture of Phleum pratense L. (5 to $6 \mathrm{~kg} / \mathrm{ha}$ ), Festuca pratensis Huds. (7 -8), Dactylis glomerata L. (4-5) or Bromus inermis Leyss. $(6-8)$ and Lolium perenne L. $(4-5 \mathrm{~kg} / \mathrm{ha})$ is recommended on medium-watered meadows with mineral soils. It can provide up to $7.8 \mathrm{t} /$ ha of dry matter with content of raw protein to $10.57 \%$.

Keywords: Cervus elaphus; hunting farm; legume-cereal grass mixture; radical improvement; cage. 